\title{
First record of genus Paramphitrite (Polychaeta: Terebellidae) in Mediterranean Sea
}

\author{
Marco Loia ${ }^{1 *}$, Luisa Nicoletti ${ }^{2}$ and Barbara La Porta ${ }^{1}$
}

\begin{abstract}
Background: The presence of species belonging to genus Paramphitrite (Terebellidae) has been recorded in the Temperate Northern Atlantic and Arctic regions (Iberian Atlantic, Norwegian and Russian seas). This paper describes the first occurrence of Paramphitrite birulai (Ssolowiew, 1899) in the Mediterranean Sea.

Methods: Sampling surveys were carried out in the North Adriatic Sea about $30 \mathrm{~nm}$ offshore Chioggia (Italy) on soft seabed at depths ranging from 29 to 32 meters. The sampling plan provided 18 stations.

Results: Seventy-four Paramphitrite birulai specimens were examined from a morphological point of view and described in comparison with the existing literature. The species was collected in sandy sediments.

Conclusions: The record of P. birulai in the North Adriatic Sea represents the first report of the genus Paramphitrite in the Mediterranean Sea extending the distribution range of this species into different ecological and environmental conditions if compared with those where it was previously recorded.
\end{abstract}

Keywords: Terebellomorpha, Paramphitrite birulai, Non-indigenous species, Sandy sediment, North Adriatic Sea

\section{Background}

Family Terebellidae Johnston 1846 was originally revised by Malmgren (1866) and the structure of his classification has been accepted with small modifications until today. Further analyses of this family were argued by Saint Joseph (1894), Hessle (1917), Chamberlin (1919) and Fauvel (1927). The most recent revisions of Terebellomorpha were carried out by Nogueira et al. (2010) and Jirkov \& Leontovitch (2013) based on previous works by Jirkov (2001) and Holthe (1986).

Genus Paramphitrite, erected by Holthe (1976), was originally composed by one species, P. tetrabranchia found in Norwegian Sea, and subsequently reported along Atlantic Iberian coast by Parapar et al. (1991). Holthe (1986) included in the genus Paramphitrite the species Amphitrite birulai Ssolowiew 1899 and in addition remarked the personal comment of Jirkov

\footnotetext{
* Correspondence: marco.loia@tiscali.it

${ }^{1}$ Laboratory of Benthic Ecology - ISPRA, Italian National Institute for Environmental Protection and Research, Via di Castel Romano 100, Rome 00128, Italy

Full list of author information is available at the end of the article
}

(Holthe 1986) suggesting that P. tetrabranchia was a junior synonym of this species. Jirkov (2001) redescribing $P$. birulai confirmed that $P$. tetrabranchia is a junior synonym of $P$. birulai.

Genus Paramphitrite is characterized by the presence of lateral lobes on segments 2, 3 and 4, not much developed, and by the presence of 13 chaetigerous thoracic segments with notochaetae having finely serrated brim on one side. These characteristics distinctly differ from genus Amphitritides Augener (1922). The presence of two pairs of dorsal dichotomous branchiae is the main difference from genera Neoamphitrite Hessle (1917) and Amphitrite (Müller 1771 sensu Hessle 1917). The body shape and the notochaetae characters resemble to Lanassa Malmgren (1866) but this genus (not present in Mediterranean Sea) differs from Paramphitrite in the absence of branchiae.

Several specimens of the genus Paramphitrite, never signaled in the Mediterranean Sea, were found in the North Adriatic Sea (Italy) during an environmental characterization of relict sand deposits, funded by the Regione Veneto local authority and carried out by the Italian National Institute for Environmental Protection 
and Research (ISPRA) of Rome (Italy), in order to evaluate the environmental compatibility of dredging activities for beach nourishment. In this work the main diagnostic characteristics of the Adriatic species Paramphitrite birulai are provided and some ecological information about its habitat and distribution is enhanced.

\section{Methods}

Sampling surveys were carried out in the North Adriatic Sea about $30 \mathrm{~nm}$ offshore Chioggia (Italy) (Fig. 1) on soft seabed at depths ranging from 29 to 32 meters, in October 2013. The sampling plan included 18 stations, strictly set for the project aimed at the environmental characterization of relict sands deposits. In each station macrozoobenthos samples were collected in two replicates using a Van Veen grab $\left(0.1 \mathrm{~m}^{2}\right.$ covering area $)$ and sieved using a $1 \mathrm{~mm}$ mesh according to methods proposed by Castelli et al. (2004). The collected material was preserved in seawater adding $4 \% \mathrm{CaCO}$-buffered formalin. Surface sediment samples were collected at each station with a box-corer. At ISPRA Laboratory of Benthic Ecology (LEB) in Rome, the morphological features of the specimens belonging to Paramphitrite birulai were examined mainly following Holthe (1976, 1986), Parapar et al. (1991), Jirkov (2001) and Jirkov \& Leontovitch (2013).

For the description of the specimens, total length and number of abdominal segments of complete specimens were considered; thorax length and width at the 9th thoracic segment were measured for all the collected material. The body measures were obtained by image analysis of photographs taken using a Zeiss SteREO Discovery V20 microscope equipped with a Zeiss Axiocam ERc5s digital camera and Zen 2011 (blue edition) software. Moreover, for each sampled station surface sediments were analysed and classified according to sediment texture percentage, following Shepard (1954) classification. Depth and geographical position (UTM projection, datum WGS84 system) were recorded at sampled stations (Table 1). The examined material, preserved in $70 \%$ ethanol for long-term storage, has been deposited in the reference collection of benthic marine organisms available at ISPRA Laboratory of Benthic Ecology in Rome.

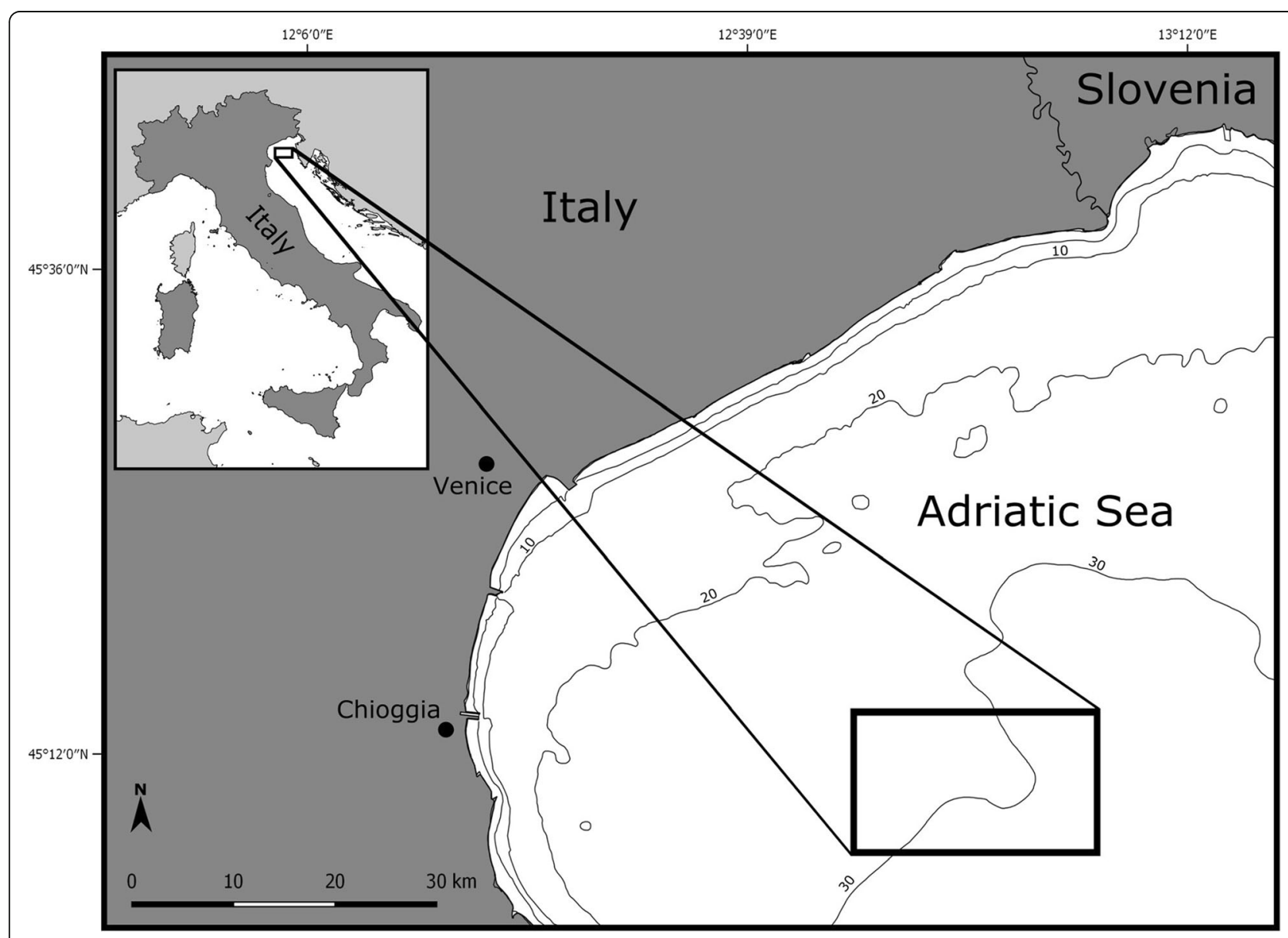

Fig. 1 Study area 
Table 1 Records of Paramphitrite birulai specimens collected in 15 sampling stations in the North Adriatic Sea (Chioggia, Italy)

\begin{tabular}{|c|c|c|c|c|c|}
\hline \multirow[t]{2}{*}{ Station } & \multicolumn{2}{|c|}{ Station coordinates } & \multirow[t]{2}{*}{ Depth } & \multirow[t]{2}{*}{ Specimens collected } & \multirow[t]{2}{*}{ Reference collection code } \\
\hline & Latitude N & Longitude $\mathrm{E}$ & & & \\
\hline RVH-C8 & $45^{\circ} 10.410$ & $12^{\circ} 54.890$ & 30.0 & 14 & ISPRA-26 \\
\hline RVH-E17 & $45^{\circ} 09.880$ & $12^{\circ} 55.733$ & 30.8 & 12 & ISPRA-27 \\
\hline $\mathrm{RVH}-\mathrm{C} 6$ & $45^{\circ} 10.505$ & $12^{\circ} 54.019$ & 29.8 & 10 & ISPRA-28 \\
\hline RVH-D14 & $45^{\circ} 10.305$ & $12^{\circ} 55.345$ & 30.5 & 7 & ISPRA-29 \\
\hline $\mathrm{RVH}-\mathrm{C9}$ & $45^{\circ} 10.562$ & $12^{\circ} 55.330$ & 30.3 & 6 & ISPRA-30 \\
\hline $\mathrm{RVH}-\mathrm{C7}$ & $45^{\circ} 10.471$ & $12^{\circ} 54.697$ & 29.9 & 5 & ISPRA-31 \\
\hline RVH-D15 & $45^{\circ} 10.211$ & $12^{\circ} 55.858$ & 30.7 & 5 & ISPRA-32 \\
\hline RVH-B2 & $45^{\circ} 10.976$ & $12^{\circ} 54.751$ & 29.9 & 3 & ISPRA-33 \\
\hline RVH-B4 & $45^{\circ} 10.959$ & $12^{\circ} 56.676$ & 31.2 & 3 & ISPRA-34 \\
\hline $\mathrm{RVH}-\mathrm{C} 12$ & $45^{\circ} 10.458$ & $12^{\circ} 56.081$ & 30.8 & 3 & ISPRA-35 \\
\hline $\mathrm{RVH}-\mathrm{C} 11$ & $45^{\circ} 10.647$ & $12^{\circ} 55.724$ & 30.6 & 2 & ISPRA-36 \\
\hline RVH-A1 & $45^{\circ} 11.618$ & $12^{\circ} 55.807$ & 31.0 & 1 & ISPRA-37 \\
\hline RVH-B3 & $45^{\circ} 10.905$ & $12^{\circ} 55.503$ & 30.6 & 1 & ISPRA-38 \\
\hline $\mathrm{RVH}-\mathrm{C} 10$ & $45^{\circ} 10.597$ & $12^{\circ} 55.547$ & 30.5 & 1 & ISPRA-39 \\
\hline RVH-E18 & $45^{\circ} 09.950$ & $12^{\circ} 56.584$ & 31.1 & 1 & ISPRA-40 \\
\hline
\end{tabular}

\section{Results}

\section{Material examined}

A total of 74 specimens of Paramphitrite birulai were examined. The number of specimens collected in each station is reported in Table 1, together with the reference collection code. The granulometric composition of the 18 sampling stations is reported in Table 2. Surface

Table 2 Granulometric composition of the 18 sampling stations

\begin{tabular}{lccrrl}
\hline Sites & Granules(\%) & Sand(\%) & Silt(\%) & Clay(\%) & Shapard classification \\
\hline RVH-A1 & 0.0 & 77.2 & 12.5 & 10.3 & Sand \\
RVH-B2 & 0.0 & 78.9 & 11.2 & 9.9 & Sand \\
RVH-B3 & 0.0 & 83.8 & 8.5 & 7.7 & Sand \\
RVH-B4 & 0.0 & 74.8 & 12.9 & 12.3 & Silty sand \\
RVH-B5 & 0.0 & 77.3 & 12.0 & 10.7 & Sand \\
RVH-C6 & 0.0 & 82.5 & 9.0 & 8.5 & Sand \\
RVH-C7 & 0.0 & 84.1 & 8.3 & 7.6 & Sand \\
RVH-C8 & 0.0 & 80.5 & 10.2 & 9.3 & Sand \\
RVH-C9 & 0.0 & 84.7 & 7.7 & 7.6 & Sand \\
RVH-C10 & 0.0 & 83.2 & 8.9 & 7.9 & Sand \\
RVH-C11 & 0.0 & 81.9 & 9.5 & 8.6 & Sand \\
RVH-C12 & 0.0 & 79.4 & 10.3 & 10.3 & Sand \\
RVH-C13 & 0.0 & 75.6 & 12.9 & 11.5 & Sand \\
RVH-D14 & 0.0 & 83.3 & 8.8 & 7.9 & Sand \\
RVH-D15 & 0.0 & 81.8 & 9.5 & 8.7 & Sand \\
RVH-E16 & 0.0 & 68.2 & 16.5 & 15.3 & Silty sand \\
RVH-E17 & 0.0 & 79.9 & 10.7 & 9.4 & Sand \\
RVH-E18 & 0.0 & 83.4 & 8.8 & 7.8 & Sand \\
\hline
\end{tabular}

sediments are classified as sand except for the stations RVH-B4 and RVH-E16.

\section{Morphological description of Paramphitrite birulai found in the North Adriatic Sea}

Among the 74 specimens examined, only 8 are complete. These last specimens range from 15.2 to 46.2 $\mathrm{mm}$ in total length, 4.2 to $7.8 \mathrm{~mm}$ in thorax length and 0.7 to $1.9 \mathrm{~mm}$ in width. Table 3 shows the values of measurements performed on the 8 complete specimens and the number of total segments counted for each specimen.

For incomplete or damaged specimens at the abdominal level, length measurements have always been made for the thoracic segments. These specimens range from 2.6 to $13.6 \mathrm{~mm}$ in thorax length and from 3.2 to $0.5 \mathrm{~mm}$ in width.

Table 3 Values of measurements performed on the 8 complete specimens

\begin{tabular}{lcccl}
\hline Specimens & total length & thorax length & width $\left(9^{\circ} \mathrm{CH}\right)$ & no. of segments \\
\hline 1 & 46.277 & 7.800 & 1.986 & 65 \\
2 & 32.022 & 6.280 & 1.492 & 69 \\
3 & 28.015 & 6.820 & 1.083 & 75 \\
4 & 24.185 & 4.581 & 0.883 & 70 \\
5 & 22.880 & 5.582 & 0.959 & 64 \\
6 & 20.260 & 5.139 & 1.160 & 67 \\
7 & 19.805 & 4.355 & 0.945 & 45 \\
8 & 15.215 & 4.239 & 0.722 & 42 \\
\hline
\end{tabular}


The body is elongated, composed of a thorax with 16 segments and a long abdomen with numerous segments (Fig. 2a). The prostomium shows a crenulated edge and many eyespots (Fig. 2f, Fig. 3b). A few short buccal tentacles are present (Fig. 2b,c,d, Fig. 3a,b), clearly grooved in their full length. Ventrally, the prostomial upper lip is broad, rounded and triangular. The lower lip is broad and thin (Fig. 2b, d, Fig. 3a). Two pairs of dorsal
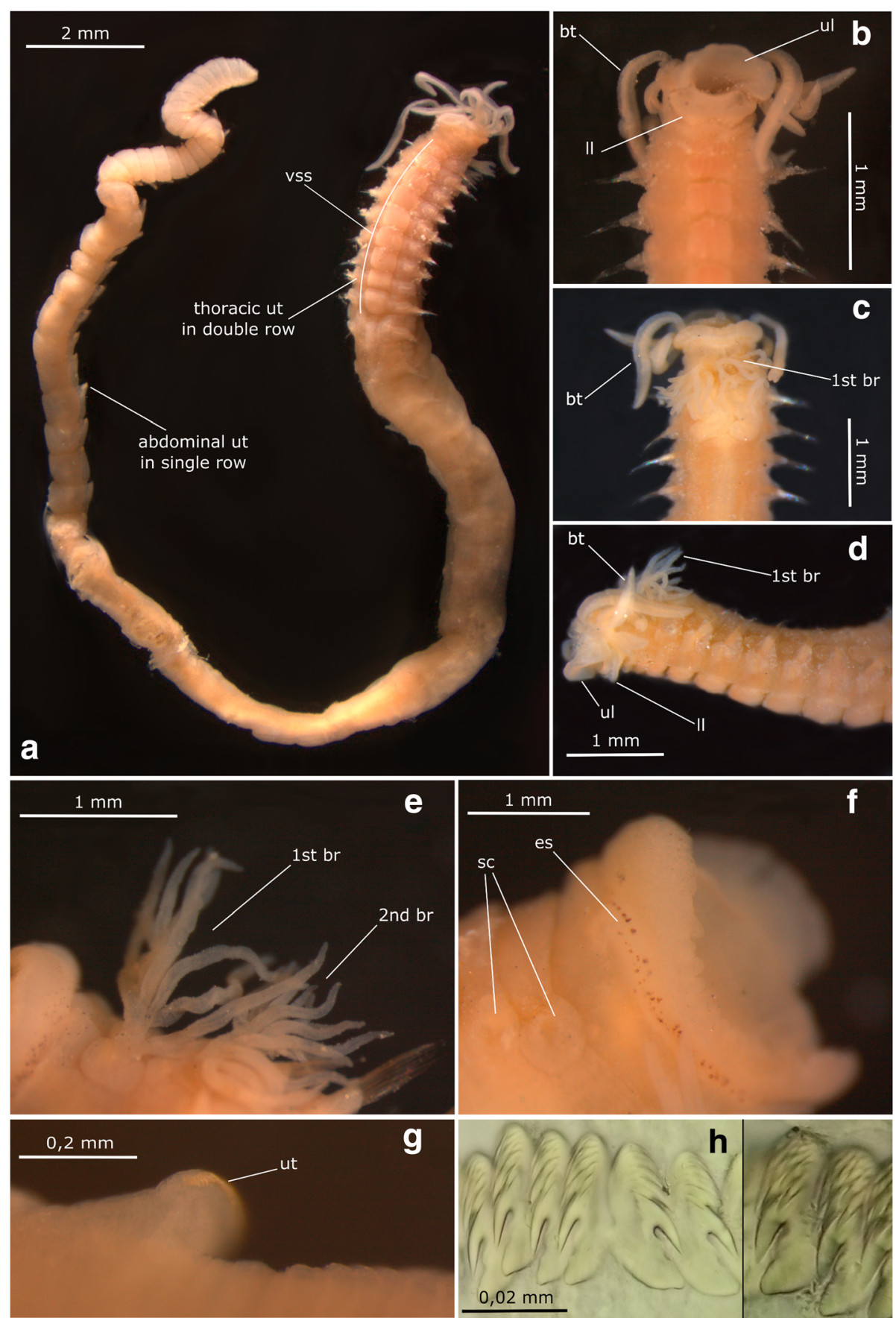

Fig. 2 Paramphitrite birulai of North Adriatic Sea: (a) entire worm, ventral view, indicating thoracic uncigerous tori in double rows, abdominal uncigerous tori in single row and ventral shields; (b) anterior end, ventral view, indicating buccal tentacles, upper lip and lower lip; (c) anterior end, dorsal view, indicating buccal tentacles and first pair of branchiae; (d) anterior end, lateral view, indicating buccal tentacles, upper lip, lower lip and first pair of branchiae; (e) anterior end, lateral view, indicating first and second pair of branchiae; (f) anterior end, dorsal view, indicating eyespots and scars of branchiae; (g) 20th abdominal segment, ventral view, uncigerous tori in single row; (h) thoracic and abdominal uncini. Abbreviations: br, branchiae; bt, buccal tentacles; es, eyespots; ll, lower lip; sc, scars; ul, upper lip; ut, uncigerous tori; vss, ventral shields 

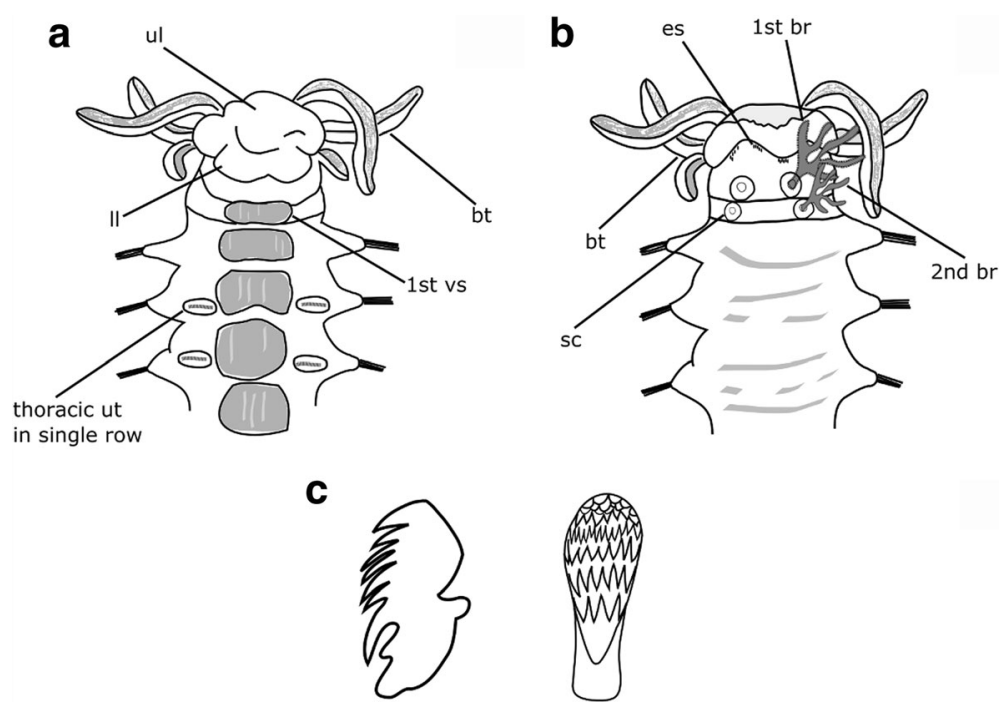

Fig. 3 Paramphitrite birulai of North Adriatic Sea: (a) anterior end, frontal view,1-6 segments indicating buccal tentacles, upper and lower lip, uncigerous tori, first ventral shield; (b) anterior end, dorsal view, 1-6 segments, indicating buccal tentacles, first and second pair of branchiae, eyespots, scars of branchiae; (c) abdominal uncini. Abbreviations: br, branchiae; bt, buccal tentacles; es, eyespots; II, lower lip; sc, scars; ul, upper lip; vs, ventral shield

dichotomous branchiae are arranged on segments 2 and 3 , with short stems and short tips. Anterior branchiae (on segment 2) are always longer than posterior ones and are nearer to the middorsum (Fig. 2c, e, Fig. 3b). On segments 2, 3 and 4 lateral lobes are present, not much developed but distinctly visible. Ten distinct ventral shields are visible on thorax (Fig. 2a) with comparable dimension and shape, except for the first one (on the second segment) thinner than the others (Fig. 3a). Notochaetae start from segment 4 and are present on 13 thoracic chaetigers. Prominent uncinigerous tori are present on thorax from segment 5, moderately long and arranged in single row (Fig. 3a). Uncini in double rows start on segment 11 (Fig. 2a) to segment 20 (4th abdominal segment). On the rest of abdomen uncini are again arranged in a single row (Fig. 2a, g). Uncini are small and avicular and appear to have six rows of teeth above the main fang (MF). Dental formula sensu Day (1967) MF:4-5:ca6:ca8: $\infty: \infty: \infty$.

The pygidium is simple with crenulated edge and no appendages. The color in alcohol is yellowish pink. Tube is composed by a thin and transparent layer of secretion incrusted with sand grains, present in just a few of the specimens examined. Tube grain size is classifiable as medium sand, using Shepard (1954) classification.

\section{Habitat and Distribution}

White Sea (Ssolowiew 1899; Norwegian Sea, on mixed sediments of clay and silt with stones, 55-138 meters (Holthe 1976; Atlantic Iberian coast, on mixed sediments of sand, clay and shell fragments, 10-15 meters Parapar et al. (1991). North Adriatic Sea specimens here described were found on sandy sediments at depths ranging from about 29 to 31 meters.

\section{Discussion}

The examination of North Adriatic specimens of Paramphitrite birulai collected in Italian coasts reveals that they conform morphologically to the specimens described by Ssolowiew (1899), Holthe (1976, 1986), Parapar et al. (1991), Jirkov (2001) and Jirkov \& Leontovitch (2013). No consistent intraspecific morphological variations have been observed in the specimens analyzed. In the studied specimens 13 thoracic segments have been always counted, comparatively to Jirkov (2001) and Jirkov \& Leontovitch (2013) that accounted 13, rarely 1415 chaetigerous segments. Ten ventral shields are clearly visible in all specimens examined, starting on segment 2 up to the 11th. The first shield, on segment 2, appears to be thinner than the others, which have comparable dimensions. This last aspect differs from Holthe (1976) description of Norwegian Sea specimens, which indicated the last two shields shorter than the previous ones. In all Adriatic specimens, ventral uncini always begins from the fifth segment (2nd chaetigerous segment).

Exclusively 10 segments (from $8^{\text {th }}$ chaetigerous segment up to $4^{\text {th }}$ abdominal segment) have uncini in double rows. From the $5^{\text {th }}$ abdominal segment the uncini are in a single row again, supported by well visible neuropodia.

The biggest $P$. birulai collected in the North Adriatic result to be longer and with a larger number of segments $(46,2 \mathrm{~mm}$ long and 65 segments) if compared with Norwegian Sea specimens described by Holthe (1986) (40 $\mathrm{mm}$ and 57 segments) and the Iberian 
specimens described by Parapar et al. (1991) (32 mm and 31 segments).

According to Holthe (1976) the tube grain size was mainly composed of sand, even if his specimens were found on mixed bottoms of clay and silt with stones, suggesting the ability of $P$. birulai to select a specific dimension of grains to build the tube.

The Adriatic records of $P$. birulai extend the habitat range of this species into different environmental conditions (grain size and depth) if compared with those where it was previously recorded (Holthe 1976; Parapar et al. 1991.

Given the reported presence of $P$. birulai exclusively in Artic, Norwegian and Iberian Atlantic Sea waters (Ssolowiew 1899; Holthe 1976, 1986; Parapar et al. 1991, the specimens collected in the North Adriatic represent the first report of this species for the Mediterranean Sea, updating the checklist of polychaete in Adriatic Sea Mikac (2015) and the checklist of flora and fauna of the Italian Seas Castelli et al. (2008). The finding of this species in the Northern Adriatic Sea supports the strong boreal affinity of this region, as well as its ecological and biogeographical similarities with the North Atlantic, documented by Bianchi et al. (2004) and Boero \& Bonsdorff (2007). The Adriatic Sea is the northernmost Mediterranean region and, together with the Gulf of Lions and the Northern Aegean Sea, the coldest sector of the Mediterranean. This sector is a geomorphologically, hydrographically and biogeographically peculiar Mediterranean region, with lower average temperatures that allow the occurrence of a specific flora and fauna with cold water affinities (Mikac \& Musco 2010; Parapar et al. 2013). Beside these aspects, considering that $P$. birulai has not intra-specific morphological variations, as often occur in polychaetes cryptic species, and that the presence of this species in Mediterranean has been never signaled, $P$. birulai might be a non-indigenous species (NIS) whose translocation from separate biogeographical regions in the North Adriatic Sea waters has been manmediated (either intentionally or accidentally) (Çinar \& Dagli 2012; Streftaris et al. 2005). Further molecular analyses could possibly assist in clarifying this hypothesis.

\section{Conclusions}

The first occurrence of Paramphitrite birulai Ssolowiew 1899 in the North Adriatic Sea represents the first record of the genus Paramphitrite in the Mediterranean Sea, previously known only from Temperate Northern Atlantic and Arctic regions (Iberian Atlantic, Norwegian and Russian seas).

\section{Acknowledgements}

The authors' acknowledgements go to their ISPRA workgroup of researchers for their assistance in the project planning, field and laboratory activities; Dr. Paola La Valle, Dr. Loretta Lattanzi, Dr. Daniela Paganelli, Dr. Alfredo
Pazzini, Dr. Raffaele Proietti and Dr. Monica Targusi. We are grateful to Dr. Fabio Bertasi for his support with the image analysis. Moreover, we would like to thanks ISPRA's Laboratory of sedimentology and environmental micropaleontology for sediments data analyses. Furthermore, we want to express our gratitude to Prof. Adriana Giangrande (University of Salento, Lecce, Italy), Dr Maria Cristina Gambi (Zoological Station of Naples "Anton Dohrn", Ischia Island, Italy), Prof. Alberto Castelli (University of Pisa, Italy), Dr. Maria Flavia Gravina (University of Rome "Tor Vergata", Italy) and Dr Marco Lezzi (University of Salento, Lecce, Italy) for their invaluable support on species identification and contribution on taxonomy of Polychaetes.

\section{Publisher's Note}

Springer Nature remains neutral with regard to jurisdictional claims in published maps and institutional affiliations.

\section{Funding}

This research has been carried out as a part of an environmental characterization project funded by the Regione Veneto local authority and carried out by the Italian National Institute for Environmental Protection and Research (ISPRA) of Rome (Italy).

\section{Availability of data and materials}

Technical report: "Caratterizzazione ambientale dei depositi sabbiosi sommersi presenti sulla piattaforma alto adriatica potenzialmente sfruttabili come cave di prestito per il ripascimento costiero nella Regione Veneto. $3^{\mathrm{a}}$ fase $1^{\circ}$ lotto: sito di dragaggio di circa $2 \mathrm{~km}^{2}$ ubicato nell'area $\mathrm{H}$. Fase di caratterizzazione ambientale ante operam". Registered at Regione Veneto local authority in 2014

The examined material has been deposited in the reference collection of benthic marine organisms available at ISPRA Laboratory of Benthic Ecology in Rome.

\section{Authors' contributions}

The authors conceived the study, participated in the field data collection, data analysis, background analysis, preparation of the manuscript, and read and approved the final manuscript.

Consent for publication

Not applicable.

\section{Competing interest}

The authors declare that they have no competing interests.

Ethics approval and consent to participate

Not applicable.

\section{Author details}

${ }^{1}$ Laboratory of Benthic Ecology - ISPRA, Italian National Institute for Environmental Protection and Research, Via di Castel Romano 100, Rome 00128, Italy. ${ }^{2}$ ISPRA, Italian National Institute for Environmental Protection and Research, Via Vitaliano Brancati 60, Rome 00144, Italy.

Received: 9 November 2016 Accepted: 1 April 2017

Published online: 12 April 2017

\section{References}

Augener H. Über littorale Polychaeten von Westindien. Sitzungsberichte der Gesellshaft naturforschender Freunde zu Berlin. 1922;3-5:38-53.

Bianchi CN, Boero F, Fraschetti S, Morri C. The wildlife of the Mediterranean. In: Minelli A, Chemini C, Argano R, Ruffo S, editors. Wildlife in Italy. Rome: Touring Editore, Milan - Italian Ministry for the Environment and Territory; 2004. p. 248-335.

Boero F, Bonsdorff E. A conceptual framework for marine biodiversity and ecosystem functioning. Mar Ecol. 2007;28 Suppl 1:134-45. http://dx.doi.org/ 10.1111/j.1439-0485.2007.00171.x.

Castelli A, Lardicci C, Tagliapietra D. Soft-bottom macrobenthos. Mediterranea marine benthos: a manual of methods for its sampling and study. Gambi MC, Dappiano M, editors. Biologia Marina Mediterranea 2004. Suppl. 11:99-131

Castelli A, Bianchi CN, Cantone G, Çinar ME, Gambi MC, Giangrande A, Iraci Sareri D, Lanera P, Licciano M, Musco R, Simonini Sanfilippo R. Annelida Polychaeta. 
In: Relini G, editor. Checklist of flora and fauna of the Italian seas. Biologia Marina Mediterranea 2008; 15 Suppl. 1: 385 pp.

Chamberlin RV. The Annelida Polychaeta [Albatross Expeditions]. Memoirs of the Museum of Comparative Zoology at Harvard College. 1919:48:1-514. http:// dx.doi.org/10.5962/bhl.title.49195.

Çinar ME, Dagli E. New records of alien polychaete species for the coasts of Turkey. Mediterr Mar Sci. 2012;13(1):103-7. http://dx.doi.org/10.12681/mms.26.

Day JH. A monograph on the Polychaeta of Southern Africa. London: British Museum (Natural History); 1967. http://dx.doi.org/10.5962/bhl.title.8596.

Fauvel P. Polychètes sédentaires. Addenda aux errantes, Archiannélides, Myzostomaires. Faune de France. 1927;16:1-494. http://dx.doi.org/10.1038/ 113528b0.

Hessle C. Zur Kenntnis der terebellomorphen Polychaeten. Zoologiska bidrag från Uppsala. 1917;5:39-258.

Holthe T. Paramphitrite tetrabranchia gen. et sp. nov. A new terebellid polychaete from western Norway. Sarsia. 1976;61:59-62. http://dx.doi.org/10 1080/00364827.1976.10411303.

Holthe T. Polychaeta Terebellomorpha. In: Marine Invertebrates of Scandinavia No.7. Oslo: Norwegian University Press; 1986. p. 1-194. http://dx.doi.org/10. 1017/s0025315400026783.

Jirkov IA. Polychaeta of the Arctic Ocean, Moscow, Yanus-K Press; 2001. 632 pp.

Jirkov IA, Leontovitch MK. Identification keys for Terebellomorpha (Polychaeta) of the eastern Atlantic and the North Polar basin. Invertebrate Zoology [aka Zoologiya Bespozvonochnykh]. 2013;10(2):217-43.

Johnston G. An index to the British Annelides. Ann Mag Nat Hist. 1846;series 1(16):433-62. http://dx.doi.org/10.1080/037454809495980.

Malmgren AJ. Nordiska Hafs-Annulater. Öfversigt af Kongiliga VeteskapsAkademiens Förhandlingar. 1866;22:355-410.

Mikac B. A sea of worms: polychaete checklist of the Adriatic Sea. Zootaxa. 2015; 3943(1):1-172. http://dx.doi.org/10.11646/zootaxa.3943.1.1.

Mikac B, Musco L. Faunal and biogeographic analysis of Syllidae (Polychaeta) from Rovinj (Croatia, northern Adriatic Sea). Sci Mar. 2010;74(2):353-70. http:// dx.doi.org/10.3989/scimar.2010.74n2353.

Müller OF. Von Würmern des süssen und salzigen Wassers. H. Mumme and Faber, Copenhagen; 1771. http://dx.doi.org/10.5962/bhl.title.14428.

Nogueira JMM, Hutchings PA, Fukuda MV. Morphology of terebelliform polychaetes (Annelida: Polychaeta: Terebelliformia), with a focus on Terebellidae. Zootaxa. 2010;2460:1-185.

Parapar J, Besteiro C, Urgorri V. Primera cita en el litoral ibérico de Paramphitrite tetrabranchia Holte, 1976 (Polychaeta, Terebellidae). Miscellània Zoològica. 1991;15:63-8

Parapar J, Mikac B, Fiege D. Diversity of the genus Terebellides (Polychaeta: Trichobranchidae) in the Adriatic Sea with the description of a new species. Zootaxa. 2013;3691(3):333-50. http://dx.doi.org/10.11646/zootaxa.3691.3.3.

Saint-Joseph A. Les Annélides polychètes des côtes de Dinard. Troisième partie Annales des Sciences Naturelles (Zoologie et Paléontologie). 1894;Series 7(17):1-395.

Shepard FP. Nomenclature based on sand, silt, clay ratios. Journal Sedimentary Petrology. 1954;24:151-8. http://dx.doi.org/10.1306/D4269774-2B26-11D78648000102C1865D

Ssolowiew M. Polychaeten-Studien. Die Terebelliden des Weissen Meeres. Annales du Museé Zoologique. Académie Impérial des Sciences St. Pétersbourg. 1899;4(2):179-220.

Streftaris N, Zenetos A, Papathanassiou E. Globalisation in marine ecosystems: The story of non-indigenous marine species across European seas. Annu Rev Oceanogr Mar Biol. 2005;43:419-53. https://doi.org/10.1201/9781420037449.ch8.

\section{Submit your next manuscript to BioMed Central and we will help you at every step:}

- We accept pre-submission inquiries

- Our selector tool helps you to find the most relevant journal

- We provide round the clock customer support

- Convenient online submission

- Thorough peer review

- Inclusion in PubMed and all major indexing services

- Maximum visibility for your research

Submit your manuscript at www.biomedcentral.com/submit

) Biomed Central 